\title{
The Complex Nature of Power and Language: Verbal Strategies in Martin Crimp's The City
}

\begin{abstract}
The purpose of the paper is to examine the dynamic relationships between language and power in The City (2008), which was written by the groundbreaking playwright Martin Crimp. In a systematic and intentional way, Crimp's language resists the established conventional standards and challenges any typical expectations for dramatic discourse. Crimp deconstructs language and dismantles its authorial guidance. He employs stimulating and inventive dialogues through word games and language strategies and devices such as repetitions, interruptions, silences and pauses, denial, concealment, other enhancement, negation, formulation, topic-shift and turn-taking. Crimp exploits language through effective and energetic rhythm, structure and form in order to depict the ethical disasters of the contemporary world. The playwright breaks the traditional dramatic form, replacing it with his unique device where the language does not communicate meaning but acts as a means of articulating power through verbal strategies.
\end{abstract}

Keywords: Contemporary British Drama; Martin Crimp; The City; language; power

\section{Kompleksna narava moči in jezika: Jezikovne strategije v drami The City Martina Crimpa}

POVZETEK

Članek raziskuje dinamične povezave med jezikom in močjo v drami The City (2008) izpod peresa inovativnega britanskega dramatika Martina Crimpa. Crimpov jezik se sistematično in namerno upira uveljavljenim standardom in spodkopava uveljavljene paradigme dramskega diskurza. Crimp dekonstruira jezik in $s$ tem avtorsko vodstvo. Svoje stimulativne in domiselne dialoge gradi z besednimi igrami ter jezikovnimi strategijami in figurami, kot so ponavljanja, prekinitve, tišine in premori, zanikanje, prikrivanje, prilizovanje, zanikanje, formulacija, menjava tem in menjavanje vlog. $Z$ energičnim in učinkovitim poigravanjem z ritmom, strukturo in obliko jezika Crimp izkorišča potencial jezika za prikaz etičnih katastrof sodobnega sveta. Dramatik ruši tradicionalno dramsko formo in jo nadomešča s svojo edinstveno strategijo, kjer jezik ne služi prenosu pomena, ampak kot orodje za artikulacijo moči s pomočjo različnih jezikovnih strategij.

Ključne besede: sodobna britanska dramatika; Martin Crimp; The City; jezik; moč 


\section{The Complex Nature of Power and Language: Verbal Strategies in Martin Crimp's The City}

\section{Introduction}

Crimp has revolutionized conventional playwriting techniques with his ingenious, aggressive and powerful use of language. In each of his plays, which he has written for The Orange Tree Theatre ${ }^{1}$ and The Royal Court, ${ }^{2}$ Crimp has systematically resisted the established norms of dramatic language. His works display that the written text can only offer an unplanned, negotiated meaning. This strong sense of ambivalence documents that the language is not the ultimate promoter or bearer of truth or meaning; on the contrary, language becomes a failure that would be regarded at best as a dynamic power for transforming the characters' lives. Crimp is perhaps the most innovative British playwright to use theatre as a medium for employing language in a slippery and ambiguous way. He transforms everyday speech into organized cruelty and subjugation. In Lacanian terms, too, "the process of language is slippery and ambiguous" and "one can never mean precisely what they say" (cited in Eagleton 1995, 146). Similarly, as Terry Eagleton asserts, meaning is "always an approximation, a near-miss, a part-failure, mixing nonsense and non-communication into sense and dialogue" $(1995,169)$. Indeed, Crimp's characters employ eloquent language stratagems to destroy, disapprove of, dominate, victimize, mislead and oppress one another. They produce language in the form of silences, pauses, interruptions, repetitions, interrogations, denial, rhetorical questions and tags. Crimp's plays are composed of word games, overlapping conversations and fragmented dialogues through a series of rich vocabulary that carry double and multiple meanings, rhythm and musicality.

A number of scholars have explored Crimp's challenging texts in terms of their postdramatic elements, violence, and urban materialism. However, the scarcity of research in uncovering Crimp's portrayal of the complex and dynamic relationships between language and power invites research such as that carried out in this paper. Crimp's language is dense with symbols, rhythm and musicality but also bears acts of verbal violence, chaos and cruelty. He uses language as a weapon, as a means of control and as a mask to hide the vicious intentions of the interlocutors. His enigmatic language refutes any sense of effortless meaning-making and easy communication.

Elizabeth Angel-Perez categorized Crimp as being among "the most innovative dramaturgies of the turn of the millennium" $(2013,79)$. She describes him as one of the most "unconventional" playwrights of the period, alongside Caryl Churchill. Like Beckett and Pinter, Crimp disintegrates the authorial framework. Indeed, in The City, Clair's diary offers to the audiences and readers an alternative "reality" to the world they have been exposed to. In this context, Crimp's challenging text verifies Roland Barthes's significant argumentation in The Pleasure of the Text in which Barthes (1975) distinguishes between "readerly/readable" and "writerly/writable" texts. While the readerly text does not challenge the reader, the writable text forces the reader forever to reestablish the text's composition (Barthes 1975). Crimp's works are largely "writerly texts" that prompt the readers/audiences to produce various kinds of meaning. The readers/audiences are challenged to decode Crimp's metaphors, individual words and symbols in order to find out

Living Remains (1981), Four Attempted Acts (1984), A Variety of Death-Defying Acts (1985), or Definitely the Bahamas (1986) and the popular Dealing with Clair (1988) as well as the more experimental Play with Repeats (1989).

No One Sees the Video (1993), The Treatment (1993), Attempts on Her Life (1997), Fewer Emergencies (2005), The Country (2000), The City (2008), In the Republic of Happiness (2013). 
whether they are related with lexical choice, unconventional theatrical forms, and the underlying socio-political concerns. As Zimmermann argues, Crimp relies on the "imaginative power of the word" (2003). The recipients constantly observe that one single word has a multitude of meanings, references and associations.

Crimp has avoided British naturalism, and he has produced the drama of denial (Sierz 2013, 162). Through his deliberate use of satire, irony and ambiguity, his plays deny audiences any easy identification with characters, clear plot resolutions and conventional situations (Sierz 2013, 162). In other words, Crimp has worked in opposition to the English naturalism by proclaiming to the audience that what they are watching is not real life but theatre (Sierz 2013, 162). Alternatively, in the last four decades, together with Martin Crimp, "Sarah Kane, Mark Ravenhill, Martin McDonagh and Anthony Neilson heralded the beginning of a distinct genre in British Theatre which is known as 'new writing'" (Middeke, Schnierer and Sierz 2011). "New writing" is characterized by plays that are contemporary in language, in their subject matter and often in their attitude to theater form (Middeke, Schnierer and Sierz 2011, ix). These plays have been defined as "confrontational, provocative, speculative, sensational, shocking, brutal, bleak, gloomy and dark" (Middeke, Schnierer and Sierz 2011, ix). This paper benefits from the terminology produced by certain linguists in reinterpreting the challenging, ruthless and innovative use of language and its influence on power relations.

A number of linguists and other thinkers have produced various theories in order to define the intriguing relationships between language/discourse and power. In this context Foucault's, Bourdieu's, and Saussure's underpinnings stand out. Foucault observes that "power is diffuse rather than concentrated, embodied and enacted rather than possessed, discursive rather than purely coercive, and constitutes agents rather than being deployed by them" (Gaventa 2003, 1). Foucault advocates that one must abstain from defining the effects of power in negative terms such as "excludes", "represses", "censors", "abstracts", "masks" and "conceals" $(1977,194)$. Against the excluding or concealing qualities, power actually produces: "it produces reality; it produces domains of objects and rituals of truth" (Foucault 1977, 194). Foucault states that "truth, morality, and meaning are created through discourse" (Pitsoe and Letseka 2013, 24). The fact that power produces actually leads us to Bourdieu who examines that each word bears a certain view, wealth and authority. The interlocutor performs in an intentional and creative way to produce certain utterances in order to gain symbolic profit.

Pierre Bourdieu (1991) identifies language as an instrument of action and power. He suggests that words are never neutral or innocent and that all words convey some form of ideology. For Bourdieu, as for Crimp, utterances are both signs of wealth and signs of authority. Bourdieu $(1991,66)$ considers language highly performative and creative. He argues that language has the power to produce existence. In accordance with Bourdieu's theory, Crimp's texts demonstrate that language does not function as a pure instrument of communication; rather, words are used to gain symbolic profit.

Bourdieu observes that "language is not only a method of communication but also a mechanism of power" $(1991,58)$. Therefore, the language used determines one's relational position in a social environment. Various uses of language restate particular positions for each interlocutor. Communicational interactions define the participants' positions and the structures in that society. Indeed, Crimp's characters compete with each other in order to be listened to by one another through such tactics as those Bourdieu has suggested. 
In addition to Foucault's "discursive power" and Bourdieu's "symbolic power", Saussure's distinction between langue and parole is also helpful in understanding the relations between language and power. Traditional playwriting is oriented towards langue, since it applies familiar conventions, which are recognizable to the majority of audience members. However, Crimp deconstructs and parodies conventional playwriting and thus makes the audience uncomfortable. Saussure uses the term parole to describe "how" a word means in actual practice - in its endless variety of contexts, intonations and syntactic arrangements (Castagno 2013, 98). Such parole suggests the potential for innovation or deviation from the conventionalized system. Indeed, parole can be defined as a gesture of openness and innovation, which proves to be a helpful tool to interpret Crimp's work.

Saussure distinguishes between "langue" and "parole", as Chomsky (1965) distinguishes between "competence" and "performance". However, Bourdieu opposes such differentiations, since speaking is a much more complex and creative activity than this rather mechanical model proposed by Saussure and Chomsky. Bourdieu states that "the recognition of the right to speak, and the associated forms of power and authority, which are implicit in all communicative situations, are generally ignored by the linguist who treats the linguistic exchange as an intellectual operation, consisting of the encoding and decoding of grammatically well informed messages" $(1991,58)$. Bourdieu therefore elaborates on the phenomenon which he describes as "symbolic power" or in some cases "symbolic violence" (1991).

\section{Martin Crimp and The City}

Crimp's theatre has the characteristics of certain trends and modes of well-established theatre conventions. He is in the same tradition as David Mamet, Samuel Beckett, and Harold Pinter in the way he examines language as part of the object of his plays. In this English-language tradition the playwrights are influenced by rhythm, musicality of language, interruptions, pauses and silences. Crimp is influenced by Pinter and Mamet in the way he uses language as a weapon for power, control, and cruelty. And, like Sarah Kane, he uses language for the sake of its "rhythm rather than its meaning" (Saunders 2002, 129). Similarly, his excess in verbal aggression can be associated with the "in-yer-face" aesthetics of the 1990s so strongly depicted in the plays of Sarah Kane, Mark Ravenhill, and Martin McDonagh. In Campbell and Katz's observation, "Crimp treats language as sequences of sounding words rather than inert symbols whose only function is to point to their encoded meanings" $(2012,462)$. As Sierz states, Crimp is fascinated by power games, and by the question of whether the urge to control is a sign of strength, or weakness $(2006,148)$.

The language Crimp uses in his plays is interestingly tense and lyrical. Instead of creating connections and smooth communication, his characters use language to create chaos. The City includes fragments that refer to scenes of suffering, war and brutality: Clair notes that Mohamed's daughter is taken away from him; Chris is surprised to learn that his swipe card does not work, which is a sign of his dismissal from work; and Jenny refers to an unnamed war-all these fragments of utterances, as a whole, explicitly convey a sense of threat and anxiety in the quotidian. The characters' inexplicable encounters actually suggest a sense of alienation. As Laura Ennor notes, the juxtapositions of painful accounts and humorous stories builds a feeling of "absurdity" (2010): Jenny's serious talk about global issues is accompanied with Chris's account about not being able to find the right meat in the frozen section. Jenny's account about an unnamed devastated city and Chris's dismissal from work depict a cruel capitalist system. Crimp's characters use language as a powerful instrument to discredit, criticize, or subordinate one another. In Foucault's sense, the characters' series of utterances create truth, morality, and meaning. 
As Bourdieu has underlined, speech is a performative act. Crimp's characters elaborate certain strategies in which they use language for power relations. In this context, this paper intends to identify the tactics the characters use to have authoritative status, uncover the degree of cooperativeness in the characters' exchanges, interpret the position of the passive counterpart under a dominant discourse, and characterize the psychology of the submissive character. It is observed that once the character has the advantage of power, he/she controls the topic, interrupts, uses command-oriented language and affects the behaviors and thoughts of his/her rival. Thus, it is essential to pinpoint the ways in which power is disseminated through language. In order to produce truth through the "discursive" and "symbolic" character of power, the characters use certain tactics and tools, such as repetitions, interruptions, silences and pauses, denial, concealment, other enhancement, negation, formulation, topic-shift and turn-taking. The next section elaborates on such language strategies and devices with examples from The City.

\subsection{Repetition}

Crimp illustrates the ways in which language itself is used as a weapon and an instrument of power. One of the devices that the characters employ in their struggle to gain power is repetition. Repetition gives intensity to the meaning, and it is an effective technique, as Leech $(1969,79)$ clarifies: "Although repetition sometimes indicates poverty of linguistic source, it can have its own kind of eloquence." Leech $(1969,79)$ highlights the essence of repetition: "By underlining rather than elaborating the message, it presents a simple emotion with force. It may further suggest a suppressing intensity of feeling - an imprisoned feeling, as it were, for which there is no outlet but a repeated hammering at the confining walls of language". Hence, repetition highlights the important ideas, and brings them to the fore. Repetition is an effective strategy, as the repetition of certain words, phrases and sentences enable the audience to identify key words, phrases or sentences of the play (Kemertelidze and Manjavidze 2013). Additionally, repetition is one of the factors that affects the attention level since the audience should "move forward to encounter a repeated element, and then immediately move our attention backward, to the previous occurrence(s) of that element, in order to recognize that a repetition has occurred" (Olson and Olson 2007, 153). Moreover, repetitions encourage the audience to reveal the characters' state of mind in that each repetition makes a contribution to lay bare the intent of the characters.

Crimp's characters mostly use repetition when they intend to refrain from revealing the truth or secrets, and when they try to escape accusations due to fear of losing power. Thus, the characters use the repeated words as weapons of concealment. They try to distract the other characters' attention to the topic in order to conceal their secrets which otherwise could probably be disclosed. Certain words that characters repeat are important signs of their effort to get the upper hand in the power game, and in Bourdieu's sense, too, the characters' utterances are both signs of wealth and signs of authority. Sierz $(2013,113)$ states that the characters who use repetitions are usually the insecure characters demanding to cover their guilt and anxiety. When they feel the threat of domination, they try to postpone the inevitable confession process by lingering over the repetitions. These characters, who are in pursuit of power, know that they have nothing to gain from confrontation, so they try to preserve their position of power by avoiding the confrontation. Crimp structures his play ingeniously by using repetitions, demonstrating a profound awareness to the power each repeated word can wield (Gillinson 2010). He cleverly uses the repetitions as weapons to threaten the opponents and to create a sense of anxiety, curiosity and mystery. After a conference in Lisbon, for example, Clair explains how nervous she felt, how her hands shook, and how she made jokes while she was delivering her paper. As can be clearly sensed in her 
utterances, she has had an enjoyable time with Mohamed at the conference, where "she couldn't help smiling" to herself:

Clair: ... I couldn't help smiling to myself.

Chris: Like you are now?

Clair: What?

Chris: Like you are now - smiling to yourself like you are now? (Crimp 2008, 50).

Her joy at the conference is so profoundly reflected in her speech that Chris counterattacks: "Like you are now - smiling to yourself like you are now?" (Crimp 2008, 50). The repetition of the interrogative "Like you are now?" indicates Chris's desire to obtain supremacy, and to submit Clair to a subservient role with little power. Chris's use of repetition imposes a feeling of threat on Clair, preventing her from providing a convincing answer. Chris subjects his victim with the help of language and postulates his predominance. However, Clair's use of the rhetorical question "what?" (which recurs throughout the play) is surprising. It is noticeable that the rhetorical question is pronounced in a situation of intense oppression. It could therefore be interpreted as a tactical evasion (Sierz 2010). Clair's choice of the question tag "what?" functions as a means of gaining time in an attempt to find an appropriate answer, and shows her endeavor to escape from Chris's authority.

However, the dynamics of power change because Clair successfully copes with Chris's repeated questions by using the supplication tactic. Supplication is one of the impression management tactics used by the powerful character to demonstrate someone's weakness and incompetence by advertising the person's shortcomings and failings (Jones and Pittman 1982). Clair identifies Chris's shortcomings as aggressive, cold and reserved. She uses the supplication tactic to subjugate Chris by implying that their marriage is in a state of decline due to the emotional barrier he has built: "I stepped towards you and you backed away. You know you did. Why did you back away from me?" (Crimp 2008, 50). Clair also manages to change the topic of conversation by using this tactic. It is essential for Clair to change the topic because her husband tries to uncover her intimate relationship with Mohamed, and to push her into a subordinate position where she cannot provide any reasonable explanation to his challenging questions.

Furthermore, a powerful effect of repetition occurs when Clair explains Mohamed's bizarre confession about his daughter, Leila (the little girl whom Clair has seen at the station). Clair explains how she has been upset to learn that Mohamed's daughter died when she was crossing the road to post a letter probably written to her father. Such is the understanding from Clair's description that "he just sits there in front of the window looking down at his hands" (Crimp $2008,51)$ - probably looking at the letter of his daughter, who died after sending it to her father. Chris is disturbed to see that Clair is fascinated by Mohamed. Here again Chris is in a superior position, putting Clair in a challenging plot:

Chris: Waiting for you to comfort him.

Clair: What?

Chris: He was waiting for you / to comfort him.

Clair: Well obviously - yes - I thought - of course I did - thought about going to him... (Crimp 2008, 51)

Clair does dare not say anything, and she is rendered incapable of giving a convincing response. 
On the other hand, Clair persistently seeks new ways which aim at Chris's subjugation and destruction. Chris's repeated expression "Waiting for you to comfort him" actually defines Clair's desire for authority by allowing her more time to plan her subsequent sentences. However, bombarded with Chris's questions, her fluency and eloquence is replaced by uncertainty and hesitation, and ultimately she finds no adequate words to escape from the subordinate position.

Crimp also uses repetition to highlight important points, such as Chris's repetition of the word "understand" throughout his monologue. The use of repetition to underline important points is illustrated in the scene when Chris repeats the word "understand" several times:

Because there are a number of things, sweetheart I don't quite understand - and some of them are things I'll never understand - and I'm quite happy for there to be some things I'll never understand - but one of the things I don't understand but that I really would like to understand is why you say that it's hot ... (Crimp 2008, 38).

Repetition also underlies the important points the characters cannot express explicitly. In the above quotation, the repetition of the word "understand" emphasizes Chris's confused mind. Here the repetition indicates how much he desires to understand Clair's indifferent attitudes to him and children. Clair's emotional distance with the family, and her strict working conditions cause Chris's outburst of tenderness. Chris seems to be incapable of expressing his longing for love because of Clair's obvious reluctance to take any responsibility for her indifferent actions. Chris's powerlessness, in turn, is underlined by a kind of speech that is marked by helpless repetition. His repetitive language is paralleled by his profound and intense emotional state.

\subsection{Interruption}

A number of linguists theorize "interruption" in comparable terms: Fairclough observes that interruption is one of the devices expressed by the more powerful person to "constrain the contributions of the less powerful participant" (1989, 135). Likewise, Simpson and Mayr $(2013,32)$ define interruption as a common device through which dominant speakers can dismiss or ignore the utterances of the subordinate speakers. Zimmerman and West (1996), too, characterize interruption as a device of exercising power and control in conversation through violating the interlocutor's speaking rights. Hence, interruption is defined as an efficient display of domination. Some Crimp scholars have already noted the use of interruptions in Crimp's plays. Lindsay Posner $(2013,189)$ in her interview with Sierz states that Crimp uses the elliptical nature of dialogue and interruptions because he is interested in the way language can be used to intrude into the characters' lives. Middeke, Schnierer and Sierz $(2011,86)$ state that interruptions, overlapping dialogues and simultaneous conversations indicate that the characters engage in a process of communication where their actions are strategic rather than communicative. Similarly, Angelaki identifies Crimp's use of overlapping dialogues as synonymous with interruptions. She $(2012,102)$ states that the characters often use overlapping dialogues with an attempt to find the right words to protect their own interests in the power games. In that sense, interruptions, overlapping dialogues and simultaneous conversations can be seen as a strategy that allows the characters to establish and strengthen their control by forcing the others to play the role of the subordinate character.

An example of the more powerful participant interrupting a subordinate person occurs at the beginning of the play when the characters are anxious about their children, who have locked themselves off. Chris does not understand what Clair means when she asks, "You're sure they're 
in there?" (Crimp 2008, 28) At this point, Jenny hopes to experience a moment of victory by interrupting Chris and explaining to him what Clair means: "She means maybe they've locked the door from the outside then run away" (Crimp 2008, 28). Jenny, assuming the role of the more powerful speaker, attempts to direct Chris through interruption; however, she cannot manage to achieve her goal because Chris is obviously irritated when Jenny interferes in the conversation with his wife, and responds to Jenny's practice of power: "I don't need you to explain to me what she means" (Crimp 2008, 28). In the final scene, a similar situation occurs: Chris does not understand what Clair means when he reads the diary, and asks, "Go on what?" (Crimp 2008, 60). Jenny interrupts Clair by explaining "She means read it - don't you?" (Crimp 2008, 60). However, unlike her husband, Clair is not irritated by Jenny's interruption; on the contrary, she supports Jenny by saying, "Yes. Read it" (Crimp 2008, 60). Their collaboration builds a relationship of power that casts Chris in a state of weakness and submissiveness. In a Foucauldian sense, the power is diffuse, and embodied through interruptions.

\subsection{Silences and Pauses}

Crimp employs silences and pauses as an effective device in the power games among the characters. The characters attempt to dominate one another by reducing him/her to silence. The characters assert their power through language. That is, without language, the characters cannot use control attempts to exert dominance in the interaction. When they lapse into silence and fail to use the control attempts, they become more submissive, and thus they allow the dominant character to have a greater influence over the decisions. Silence may suggest that characters are "stopped short by their own ungoverned thoughts or trying to conceal their real emotions" (Sierz 2013, 114). However, Fivush states that it is necessary to distinguish between "being silenced and being silent" (2010). While being silenced signifies a loss of power, being silent can be regarded as a tactic to gain power. In this respect, silence is used as a means of exerting control rather than accepting control. Silence is used to exert power, because it indicates that the powerful characters need not explain or justify their actions (Fivush 2010). The powerful characters deliberately silence themselves in order not to share certain experiences with the others. Hence "silence is not always a symbol of passivity and powerlessness; contrarily, it can be used as a strategic defense against the powerful" (Gal 1971, 176). As Glenn $(2002,263)$ states, "like the zero in mathematics, silence is an absence with a function". Linguist Susan Gal, drawing from Michel Foucault's work, notes that the silent listener is usually the person "who judges, and who thereby exerts power over the one who speaks" $(1971,171)$. Furthermore, Glenn states that "the question is not whether speech or silence is more productive, more effective, more appropriate; rather, it is one of a rhetoricity of purposeful silence when it is self-selected or when it is imposed" $(2002,263)$. Glenn $(2002,264)$ argues that "when silence is our rhetorical choice, we can use it purposefully and productively but when it is not our choice, but someone else's for us, it can be insidious". Similarly, Gutscher $(2014,85)$ draws a comparison between silence and the shelter that the characters seek in order to escape the attacks of the verbal violence. Gutscher $(2014,85)$ notes that silences are never empty; contrarily, they are charged with uncertainty and danger. In Crimp's play, silence is not imposed by the others: it is the powerful character's preference to remain silent. Indeed, silence often involves an unspoken conversation in The City. Saying nothing becomes a particularly important way of saying something (Silverberg 2013, 79). Therefore, silence is a powerful tool that is as important as language. Silences are not unproductive and passive; they are used as tactical choice and bear certain impositions. The characters can use silence to maintain "the position of power, resist the domination, or submit to subordination" (Glenn 2004, 153). Silence has "the potential to profoundly disrupt, shift, and deploy power" (Glenn, 2004, 5). 
As is clearly seen in the interchange below, while Clair forces Chris to make a satisfying explanation about his question, Chris does not respond to her and prefers to remain silent. He uses silence as a means of ignoring what Clair - here the more powerful participant - asks. Crimp's use of silences and pauses is reminiscent of the power of silences in Harold Pinter's plays. Silence functions as a shield to protect Chris from repression at least in the short term. Hence, silence is associated with a powerful communicative tool rather than an absence of communication (Jaworski 1992, 136). However, the more powerful participants may compel the less powerful participants to break the silence by demanding answers and explanations to a number of successive questions (Fairclough 1989, 46), as in Clair's sequential questions: "Me? What makes you say that? What makes you say that? Where are you going?” (Crimp 2008, 16) Clair's fundamental aim in her excessive questioning is to take the control from Chris. When Chris does not respond to Clair's utterances, she breaks his silence:

Chris: What big change in her life?

Clair: Leaving her father of course. Living with her aunt.

Pause.

Have you not been listening? (Crimp 2008, 9).

The above dialogue is one of many that display the lack of communication between married couples. However, Crimp insists that his plays are actually all about "communicating" (Sierz 2013 , 105). He maintains that "some of his characters would prefer, at certain moments, not to communicate, but that does not mean they cannot" (Sierz 2013, 105). Hence, pauses and silences are used for more intentional strategic reasons than they simply appear. In the dialogue above, Chris's attempt to express his disbelief in Clair's story ends in his silence. This dialogue also shows how characters are let down by the absence of language. Being afraid of losing her authority, Clair waits for an answer. However, Chris deliberately refuses to utter a word in order to gain power. As a matter of fact, silence can be employed as a weapon which not only serves to defend but which can also be used as an effective tool to compete with the verbal mastery. In this respect, by consciously choosing silence as an instrument of control, Chris attempts to create an intense tension for Clair, and reminds her of the risk of losing power.

\subsection{Denial}

The characters use denial as a weapon in verbal power play. Denial stems from the characters' need to avoid the disturbing facts to preserve their authority. In this respect, as in the case of silence, denial, too, contains avoidance. Denials deliberately involve refusing to acknowledge the disturbing facts so as not to lose power. Thus, "rather than simply failing to notice something, denial entails a deliberate effort to refrain from noticing it" (Zerubavel 2006). In Crimp's play, fear is one of the main reasons underlying the characters' denial process: what the characters fear is, indeed, the fear of losing power. When the characters feel that their dominant position is being threatened, they try to avoid that disturbing fact by resorting to denials. Therefore, the characters adopt other similar verbal strategies to that of denial to "avoid confrontation with the disturbing information, which can be identified as displacement, reinterpretation, and concealment" (Rousseau 2014). The interlocutors use these strategies as defense mechanisms which occur when the characters are faced with a personal problem, and "refuse to acknowledge that the problem is indeed personal" by reshaping the external reality (Rousseau 2014). This is what Cohen calls "implicatory denial", which means that "the involvement of the speaker is 
denied through apparent detachment" $(2001,5)$. Implicatory denial occurs when the characters encounter a confusing and conflicting situation where they feel helpless and powerless. A series of examples of this sort can be seen in The City through "the determiner 'that', whose function is to create temporal, spatial, and emotional distance, as opposed to 'this', which involves proximity" (Rousseau 2014). By using such a defense mechanism, the characters try to turn "a personal disturbance into a foreign one" (Rousseau 2014). This strategy has been adopted in The City by Clair, a character who denies the existence of other characters by inventing an external imaginary world. Clair's defense strategy functions to displace the threat from the real world into the imaginary world: "I invented characters and I put them in my city" (Crimp 2008, 62). The displacement strategy also involves the spatial rejections. Indeed, The City plays "wicked games" with the audience's expectations (Sierz 2011). The characters are engaged in the conventional and intimate conversations behind which there is desire, intent and the hovering threat of violence. Even in the most banal conversations, the characters voice their own fears or desires rather than attempting to comfort one another (Woohead 2010). In the play, the dichotomy of inner/outer is vital for establishing that the domestic space is physically invaded by the outside evil world (Sakellaridou 2014). This is again denying the safety of the inner domestic space.

At times the characters feel reluctant to verbalize the unpleasant information, and refuse to "give it a voice, either by not naming or by renaming the reality which is unbearable to acknowledge" (Rousseau 2014). Relevantly, then, the characters use the indefinite article "this" when they prefer to un-name things. Crimp's characters usually use "this" as a cataphoric device that postpones the readers' grasp of the situation. For example, the audience understands that Clair has met a man whose identity is unclear to him. When talking about the man, Clair first uses "this": "I was waiting on the station concourse this afternoon after my meeting - waiting for my train - when this man came up to me and said, have you seen a little girl about so high - I've lost her" (Crimp 2008 , 7). The use of "this" is only partially explained later: "Because it turned out I knew him" (Crimp 2008, 10). Crimp would soon expose that the man is a famous writer: "He's this writer that everyone's talking about" (Crimp 2008, 10). The characters sometimes prefer renaming to un-naming, which in Cohen's (2001) terms is "interpretive denial". In the interpretive denial process, facts are not contradicted, but they are enriched with different meanings as a tactic. For example, Chris does not want to acknowledge that Clair is indifferent towards her children, and he is clearly seeking to re-frame and justify Clair's actions by re-configuring what happened: "She was so worn out that she didn't even go into your room, she didn't have the strength to push the hair back behind your ear..." (Crimp 2008, 46). Chris acknowledges the reality only partially, and re-frames the events so that "what happened is really something else" (Cohen 2001, 103).

\subsection{Concealment}

The other strategy to avoid the unpleasant information is concealment, which is achieved through minimization (Rousseau 2014). Rousseau notes that Crimp's characters consistently "use limiting focusing adverbs such as 'only', 'just', or 'simply" (2014). For example, Chris uses one of the limiting focusing adverbs "only" when he talks about losing his job: "My day was good. Only my card wouldn't swipe" (Crimp 2008, 8). Chris uses "only" as a kind of psychological defense mechanism to lessen the psychological burden of losing his job. A similar verbal avoidance can be detected in Chris's other speeches, for example, when he talks about the diary Mohamed gave to Clair: "And he just gave it to you? The man - this man - he just gave it to you?" (Crimp 2008 , 10). In Chris's speech "just" shows that Chris tries to block the disturbing information by denying or distorting the reality. He wants to convince himself that his wife is indeed reliable by 
minimizing her inclination to betrayal. Thus, Crimp's characters make the screening function of the language obvious by displacing, reinterpreting, and finally concealing the disturbing elements. As Harold Pinter (1976, 14-15) notes:

The speech we hear is an indication of that which we don't hear. It is a necessary avoidance, a violent, sly, anguished or mocking smoke screen which keeps the other in its place. When true silence falls we are still left with echo but are nearer nakedness. One way of looking at speech is to say that it is a constant stratagem to cover nakedness.

In The City, language is used not as a tool for communication but it is used as a screen preventing truth from appearing overtly.

\subsection{Other Enhancement}

Other enhancement is a tactic that asserts that people are attracted to others who seem to be attracted to them (Byrne 1961). The principle behind this tactic is that people tend to favor others who make positive compliments about them (Tedeschi and Riess 1981). We see Clair using the other enhancement tactic to gain power and control over Chris by trying to maintain a positive interpersonal relationship with him. The unstable, shifting status of power is clearly seen when Clair realizes the dramatic change in Chris's attitude: "You have completely changed... Look at you. Much more confident... Your whole attitude's changed... Even the way you're standing" (Crimp 2008, 36-37). In fact, the reason for her favorable comments or rather compliments, lies in her innermost feelings of jealousy. When Chris explains to Clair how he has found the job at the butcher's, he mentions a woman, Indy, whom he has met at a pub. This piece of information about another woman actually changes the power balance. Chris's liaison with another woman captures Clair's attention, as she is very aware of her less powerful role; Clair appears to be jealous of this woman:

Clair: It's not as if you'll ever see her again.

Chris: No.

Clair: Will you?

Chris: No. Jesus Christ, no, I hope not.

Clair: Then stop thinking about it.

Chris: I'm not thinking about it.

Clair: Good - because you should stop thinking it. (Crimp 2008, 35-36)

Here, Clair's choice of words highlights the submissive role she assigns to Chris. Chris is inactive and entirely dependent upon what she chooses to do. There is even a feeling of menace in her insistent recommendation that he should not care about the opinion of a complete stranger whom he will not see again. Excluding him from constructing his own identity and self-determination, Clair tries to maintain her superior position.

\subsection{Negation}

Negation is one of the devices used to empower the authority. Fairclough $(1989,125)$ indicates that negation is the basic way through which the readers distinguish "what is not the case in reality from what is the case". In this respect, employing negations has a great impact on the speaker to discover the real intentions, facts and truth. To illustrate, while Chris and Jenny 
discuss how the children lock themselves in the playroom, Chris's negative sentence creates a powerful effect, and plays a significant role in limiting Jenny's action: “...if they haven't unlocked that door in another... what shall we say?" (Crimp 2008, 28). The playwright could make the same point in a positive attempt by the following utterance: "if they have locked that door in another ... what shall we say?" However, in that case, the corresponding positive assertion would not create the same emphasis as in the negative sentence. Fairclough also notes that, depending on intonation and the other factors, using negative questions may suggest that "I assume that $\mathrm{x}$ is the case, but you seem to be suggesting it isn't, surely it is?" (Fairclough 1989, 46). Such operation of power can be clearly observed in the following exchange, when Clair is preoccupied with translating. By using a negative question "Don't you get bored with it?" (Crimp 2008, 16), Chris implies that he is really bored with Clair's incessant working:

Chris: Don't you get bored with it?

Clair: Mmm?

Chris: Translating. Don't you get / bored with it? (Crimp 2008, 16)

Fairclough (1989) also suggests that using a declarative sentence rather than an interrogative sentence with question tags creates the effect that of the negative question, which is clearly seen in the interchange between Clair and Chris when they talk about Mohamed:

Clair: The writer, Mohamed. What makes you think I've dismissed him from my thoughts?

Chris: Well haven't you?

Clair: Yes - no - no - not necessarily. (Crimp 2008, 14)

Chris's "Well haven't you?" is a way of implying that "You should have forgotten Mohamed but you probably have not". This question also allows Chris to establish dominance over Clair, since it pushes her into a powerless position where she hesitates over whether or not to admit that she cannot dismiss Mohamed from her thoughts.

\subsection{Formulation}

The other device widely used to exert power is formulation. Formulation is "a rewording of what has been said, or it is a wording of what may be assumed to follow from what has been said, what is implied by what has been said" (Fairclough 1989, 136). Formulation is usually used for checking understanding and reaching an agreement (Fairclough 1989, 136). However, it is also used to exercise control by limiting the potential contributions of the subordinate character (Fairclough 1989, 136). Formulation is described as a weapon and a control device, enabling participants to "accept one's own version through constraining their options for further contributions" (Simpson and Mayr 2013, 34). In the following exchange, Clair uses formulation to challenge Chris who, in turn, disconfirms it:

Clair: A flow of speculation.

Chris: Yes. And you'd have no idea why. Because after all Jeanette is very ordinary-looking. Clair: Is she?

Chris: And yet she has this power.

Clair: Over men.

Chris: Over what? - no - that's not at all what I mean - I mean over everyone - men and 
women / likewise.

Clair: So you're saying you may lose your job?

Chris: I'm just saying what Bobby told me Jeanette said to him at lunch. It doesn't mean I'm going to kill myself. I have no plans to hang myself from a tree, if that's what you think [...] I hardly think I'm unemployable. And even someone who's spent a whole meeting with their head down drawing interlocking shapes on the agenda - or imaginary animals - will often come up to me afterwards and thank me for being the only person in the room... (Crimp 2008, 13)

Clair's fourth turn - "So you're saying you may lose your job?" - formulates what Chris has been struggling to confess but unable to achieve. Clair reaches the conclusion that Chris has lost his job, and accordingly her formulation seems to force Chris to confess it. On the other hand, Chris has been trying to hide his powerlessness by trying to appear unconcerned about losing his job; however, he could not succeed in hiding his frustration.

\subsection{Topic-shift and Turn-taking}

Maintaining power can also be described through an analysis of topic shifts and turn-taking in various conversational situations. Fairclough $(1989,136)$ indicates that the topic may be determined and controlled by the more powerful participant. The powerful participant is often in a position to specify the starting and ending points of the interaction, and to disallow non-relevant contributions. From the very first moment of the play, it can be realized that the characters Clair, Chris, and Jenny are only concerned about their own cities - the different cities that depict different stories, realities, and expectations compete for dominance, without paying any attention to the other. The characters ignore other characters' stories which is confirmed when Chris starts to recount the same story for the second time, but Clair fails to notice it:

Chris: I'll tell you something that will make you laugh. You know this morning when I got to my building? Well my card wouldn't swipe. I tried and tried but it would not swipe. So I tapped on the glass but the only person in there at that time of the morning was a cleaner so the cleaner came over to the glass... No. I've told you this. Have I already told you this?

Clair: Go on.

Chris: But I've already told you this.

Clair: Told me what? Have you? (Crimp 2008, 15)

Crimp's language is characterized by "trademark sequences of 'unpartnered' conversation: two people talking as if the other is listening, though the responses never mesh" (Sierz 2013, 120). There is continuous and intentional disconnection in the linguistic exchanges. As Brown and Yule $(1983,84)$ describe, the characters "speak on a topic" rather than "speaking topically", that is, they change the topic raised by the others towards a topic that they want to bring into the limelight:

Clair: ... He's this writer that everyone's talking about ... it was completely fascinating to find myself sitting in a café with this writer that everyone's talking about. Because he never gives any interviews, but there he was sitting in this café opening his heart to me. About his time in prison - and the torture there [...] during all the nights and days he waited for them to come. 
Chris: Them?

Clair: His torturers.

Chris: I see.

Clair: The people who determined to/break his will.

Chris: I had a visit from Bobby today. (Crimp 2008, 11)

The characters share their thoughts through monologues rather than dialogues, and they do not listen to each other. Zimmerman and West (1996) argue that the difference between a monologue and dialogue is not the number of the people present but the articulation of the roles of speaker and listener. In this perspective, the three characters of the play are only speakers rather than listeners. As seen in the interchange above, characters are so preoccupied with recounting their own stories that neither can hear the other. While Clair enthusiastically exchanges a story that she has had a bizarre interaction with a man named Mohamed who turns out to be a famous writer, Chris shows a significant lack of interest in it by changing the topic to that of Bobby Williams's visit. This is noticeably similar to the scene where Chris shifts the topic towards another to avoid a challenging situation:

Jenny: I'm sure I've seen you -

Chris: Oh?

Jenny: Yes - standing at an upstairs window.

Chris: You're right.

Jenny: Because when you opened the door I thought to myself: I've seen that face before in the supermarket or something - or standing at an upstairs window looking a bit sad.

Chris: Can I take your coat?

Jenny: What?

Chris: Your coat. (Crimp 2008, 19)

In the exchange above, Chris does not acknowledge Jenny's contribution. On the contrary, he continues with a different topic, one which is not connected with Jenny's utterances. The initial topic reflects the strong possibility that they have previously met, because the reader can assume from Jenny's insistent remarks that it is not the first time they saw each other: "We know each other, don't we. I've seen you somewhere - was it the opticians? Or I know what it is - looking in a freezer cabinet in the supermarket..." (Crimp 2008, 19). However, Chris changes it to a nonrelevant topic by offering to take Jenny's coat. Chris's sudden topic change can be explained by the fear of confronting the reality that he watches Jenny standing at an upstairs window (Crimp 2008, 19) in the mornings when Jenny drives back totally exhausted from the hospital. Chris also tries to change the topic when Jenny wants to talk to Clair. He changes the topic by saying, "I'll take your coat" (Crimp 2008, 19). Here Chris is both curious and anxious about what Jenny is going to talk to Clair. He feels so uneasy that he cannot even complete his question, and he can only say to Jenny: "Why have you -?" (Crimp 2008, 21). The power relation is restructured when Jenny interrupts Chris and attempts to defeat him by formulating his question as "Why have I come?” (Crimp 2008, 22).

Chris: Then why have you -?

Jenny: Yes?

Chris: Then why have you -? 
Jenny: Yes? Come? Why have I come?

Chris: Exactly.

Clair: To talk to me.

Chris: Mmm?

Clair: To talk to me.

Jenny: That's right.

Chris: I'll take your coat.

Jenny: No. Keep away.

Chris: I'm sorry?

Jenny: I said: keep away from me. (Crimp 2008, 21-22)

Clair's "To talk to me" shows her effort to oppress Chris, which causes Chris to lose power as the speech results in his alienation from the conversation. The use of "me" rather than "us" causes Chris to feel that he is not personally addressed. His feeling of alienation increases when Jenny asserts her power and authority by commanding Chris to keep away from her.

Though Jenny manages to stay calm when speaking to Clair about the atrocities in the secret war, her utterances carry a strong sense of annoyance. She complains that when she works on the night shift, her daytime sleep is disturbed by the couple's children playing in the garden. What prevents her from sleeping is not the noise the children make but the atrocities in her mind. However, as pointed out above, the characters are not concerned with the stories of others even if those stories are about a war which involves "attacking a city - pulverizing it -, in fact - yes - turning this city - the squares, the shops, the parks, the leisure centers and the schools - turning the whole thing into a fine grey dust" (Crimp 2008, 22). The violence of atrocities which the audience learns from Jenny's monologue is also uncovered in one of the limericks that his child recites to Chris:

Girl: There once was a child in a drain

Who longed for the sound of the rain

But when the storm broke

The poor child awoke

In a stream of unbearable pain. (Crimp 2008, 42)

Although Jenny emphasizes the traumatic and cruel events by the intensity of her language, Chris shows indifference towards it. He appears to be incapable of displaying any sense of sympathy or empathy to the horror stories that include the secret mission of Jenny's husband. He asks how the war is going as if it was an ordinary event: "How's the war? ... Going well? ... Going well, is it?" (Crimp 2008, 58). Likewise, Clair is quite surprised at Mohamed's calm speech about the torture in the prison. She says he is opening his heart to her "all quite normally - just a normal conversation" (Crimp 2008, 11) despite the torment he experienced in the cell. Similarly, Clair refers to a series of atrocities in a devastated city inside her where "the houses, the shops... minarets lay on the ground next to church steeples..." (Crimp 2008, 62). The city has turned into dust without any inhabitants to write about. Hence, she invents characters. Here, although Clair refers to a sequence of familiar scenes from the contemporary world, she does not go into details. She employs language as a mask to cover brutality and horror, retreating into her private world and creating characters and stories. 


\section{Conclusion}

For Crimp, dialogue is naturally cruel: He proposes that "there is something inherently cruel about people talking to each other" (Sierz 2013, 88). He employs perfectly civilized and polite exchanges in order to suppress feelings of terror, disgust and hatred. All of the linguistic exchanges above show that Crimp expertly uses evasion, miscommunication, and incomprehension (Sierz 2013, 120). The dialogues consist of overlapping lines, hesitations, pauses and silences, interruptions, and repetitions. Each and every word may carry multiple meanings. On the surface, the exchanges are perfectly civilized and calm; however, beneath the lines there is a sense of violence, terror, and ruthless competition for power. The written text or the uttered words can only compromise an unexpected and negotiated meaning. To return to Bourdieu's notion of "symbolic profit", the characters' utterances are both signs of wealth and signs of authority. Therefore, language functions more like a mechanism of power than a mere means of communication.

Crimp uncovers the sinister tone veiled under banality and politeness. A series of atrocities is highlighted underneath the civilized utterances. Ironically, the characters act as witnesses to certain atrocities, but at the same time, they ignore the crimes of violence that are committed before their eyes. In this respect, The City reminds the contemporary audiences of Harold Pinter's Ashes to Ashes, in which the protagonist denies and censors any of the $20^{\text {th }}$ - century atrocities, from the murder of Jewish or Bosnian people, to the atrocities in the Middle East. Like Pinter, Crimp also criticizes the self-censorship, ignorance, and complicity of the Western civilization. People are so indifferent to those atrocities that it is quite normal for them; as Clair says, "just like me talking to you now - about torture - about the bucket on the cement floor - all quite normal" (Crimp 2008, 11). His characters use language as a camouflage in order to veil the troublesome facts in their lives. Along with the characters' anxiety and depression, the audiences also witness the major ethico-political despairs in today's urban lifestyles.

\section{References}

Angelaki, Vicky. 2012. The Plays of Martin Crimp: Making Theatre Strange. London: Palgrave Macmillan.

Angel-Perez, Elizabeth. 2013. "Language Games and Literary Constraints: Playing with Tragedy in the Theatre of Caryl Churchill and Martin Crimp." In Contemporary British Theatre: Breaking New Ground, edited by Vicky Angelaki, 79-95. London: Palgrave Macmillan.

Aragay, Mireia, Hildegard Klein, Enric Monforte, and Pilar Zozaya. 2007. British Theatre of the 1990s: Interviews with Directors, Playwrights, Critics and Academics. London: Palgrave Macmillan.

Barthes, Roland. 1975. The Pleasure of the Text. New York: Hill and Wang.

Bourdieu, Pierre. 1990. The Logic of Practice. Oxford: Polity Press.

—. 1991. Language and Symbolic Power. Cambridge: Polity Press.

Brown, Gillian, and George Yule. 1983. Discourse Analysis. Cambridge: Cambridge University Press.

Byrne, Donn. 1961. "Interpersonal Attraction as a Function of Affiliation Need and Attitude Similarity." Human Relations 14(3): 283-89. doi:10.1177/001872676101400305.

Campbell, John, and Albert Katz. 2012. "Are There Necessary Conditions for Inducing a Sense of Sarcastic Irony?” Discourse Processes 49(6): 459-80. doi:10.1080/0163853X.2012.687863.

Castagno, Paul. 2013. New Playwriting Strategies: A Language-Based Approach to Playwriting. London: Routledge. 
Chomsky, Noam. 1965. Aspects of the Theory of Syntax. Cambridge, MA: MIT Press.

Cohen, Stanley. 2001. States of Denial: Knowing about Atrocities and Suffering. Cambridge: Polity Press.

Crimp, Martin. 2008. The City. London: Faber and Faber.

Eagleton, Terry. 1995. Literary Theory. Oxford: Blackwell.

Ennor, Laura. 2010. “Tron to stage Martin Crimp's The City.” The List, February 10. Accessed October 11, 2015. https://www.list.co.uk/article/23639-tron-to-stage-martin-crimps-the-city/.

Fairclough, Norman. 1989. Language and Power. London: Longman.

Fisher, Diane. 2007. “"The Long Way Around”: Space, Place, and Syntax in "White Highways.”' In James Still: Critical Essays on the Dean of Appalachian Literature (Contributions to Southern Appalachian Studies), edited by Ted Olson and Katie Olson, 147-56. McFarland: University Press of Kentucky.

Fivush, Robyn. 2010. "Speaking Silence: The Social Construction of Silence in Autobiographical and Cultural Narratives.” Memory 18(2): 88-98. doi:10.1080/09658210903029404.

Foucault, Michel. 1977. Discipline and Punishment: The Birth of the Prison. New York: Vintage Books.

Gal, Susan. 1991. "Between Speech and Silence: The Problematics of Research on Language and Gender." In Gender at the Crossroads of Knowledge: Feminist Anthropology in the Postmodern Era, edited by Micaela di Leonardo, 175-203. California: University of California Press.

Gaventa, John. 2003. "Power after Lukes: An Overview of Theories of Power since Lukes and Their Application to Development." Brighton: Participation Group, Institute of Development Studies.

Gillinson, Miriam. 2010. “Threatening Repetition.” Culture Wars, October 8, Accessed May 9, 2015. http:// www.culturewars.org.uk/index.php/site/article/threatening_repetition/.

Glenn, Cheryl. 2002. "Silence: A Rhetorical Art for Resisting Discipline(s)". Journal of Advanced Composition 22(2): 261-91.

—. 2004. Unspoken: A Rhetoric of Silence. Carbondale: Southern Illinois University Press.

Gutscher, Lea Jasmin. 2014. Revelation or Damnation? Depictions of Violence in Sarah Kane's Theatre. Hamburg: Anchor Academic Publishing.

Jaworski, Adam. 1992. The Power of Silence: Social and Pragmatic Perspectives. London and New York: Sage Publications.

Jones, Edward, and Thane Pittman. 1982. “Toward a general theory of strategic self-presentation.” In Psychological Perspectives on the Self, Volume 1, edited by Jerry M. Suls, 231-62. Hillsdale: Lawrence Erlbaum Associates.

Kemertelidze, Nino, and Tamar Manjavidze. 2013. "Stylistic Repetition, Its Peculiarities and Types in Modern English.” European Scientific Journal 9 (July 2013 Special Edition): 1-8. Accessed October 10, 2015. http://www.eujournal.org/index.php/esj/article/view/1610.

Leech, Geoffrey. 1969. A Linguistic Guide to English Poetry. London: Routledge.

Middeke, Martin, Paul Schnierer and Aleks Sierz. 2011. The Methuen Drama Guide to Contemporary British Playwrights. London: A\&C Black.

Olson, Ted, and Katie Olson. 2007. James Still: Critical Essays on the Dean of Appalachian Literature (Contributions to Southern Appalachian Studies). McFarland: University Press of Kentucky.

Pinter, Harold. 1976. Complete Works: One. New York: Grove Weidenfeld.

Pitsoe, Victor, and Moeketsi Letseka. 2013. "Foucault's Discourse and Power: Implications for Instructionist Classroom Management." Open Journal of Philosophy 3(1): 23-28. doi:10.4236/ojpp.2013.31005. 
Rousseau, Aloysia. 2014. “'Didn't See Anything, Love. Sorry': Martin Crimp's Theatre of Denial.” Contemporary Theatre Review 24(3): 342-52. doi:10.1080/10486801.2014.921052.

Sakellaridou, Elizabeth. 2014. “'Oh My God, Audience Participation!': Some Twenty-First-Century Reflections." Comparative Drama 48(1-2): 13-38. doi:10.1353/cdr.2014.0005.

Saunders, Graham. 2002. "Love Me or Kill Me": Sarah Kane and the Theatre of Extremes. Manchester and New York: Manchester University Press.

Sierz, Aleks. 2006. The Theatre of Martin Crimp. London: Methuen.

—. 2010. "The Country, Arcola Theatre." Accessed September 10, 2015. http://www.sierz.co.uk/reviews/ country-arcola-theatre/.

- 2011. Rewriting the Nation: British Theatre Today. London: Methuen Drama.

- 2013. The Theatre of Martin Crimp. London: Bloomsbury.

Simpson, Paul, and Andrea Mayr. 2013. Language and Power: A Resource Book for Students. London: Routledge.

Tedeschi, James T., and Mark Riess. 1981. "Identities, the Phenomenal Self, and Laboratory Research.” In Impression Management Theory and Social Psychological Research, 13-20. New York: Academic Press.

Woohead, Cameron. 2010. “The City.” The Age, September 7, Accessed May 5, 2010. http://redstitch.net/ gallery/the-city/.

Zerubavel, Eviatar. 2006. The Elephant in the Room: Silence and Denial in Everyday Life. Oxford: Oxford University Press.

Zimmerman, Dean H., and Candace West. 1996. “Sex roles, interruptions and silences in conversation.” In Current Issues in Linguistic Theory 125, Towards a Critical Sociolinguistics, edited by Rajendra Singh, 21136. Amsterdam: John Benjamins. doi:10.1075/cilt.125.12zim.

Zimmermann, Heiner. 2003. "Images of Woman in Martin Crimp's Attempts on Her Life." European Journal of English Studies 7: 69-85. doi:10.1076/ejes.7.1.69.14827. 